Kalamatika: Jurnal Pendidikan Matematika

\title{
IMPROVING STUDENTS LEARNING OUTCOMES IN BLENDED LEARNING THROUGH THE USE OF ANIMATED VIDEO
}

\author{
Nicky Dwi Puspaningtyas ${ }^{1}$, Marchamah Ulfa ${ }^{2}$ \\ ${ }^{1}$ Universitas Teknokrat Indonesia, Jl. Z.A. Pagar Alam No. 9-11, Bandar Lampung, Indonesia. \\ nicky@teknokrat.ac.id \\ ${ }^{2}$ Universitas Teknokrat Indonesia, Jl. Z.A. Pagar Alam No. 9-11, Bandar Lampung, Indonesia. \\ marchamah@teknokrat.ac.id
}

\section{ABSTRACT}

This quantitative study aims to determine the improvement of student learning outcomes in blended learning through the use of animated videos. The study was conducted on 35 students of Universitas Teknokrat Indonesia in the Business Mathematics course. Pretest and posttest are given to subjects to determine learning outcomes before and after treatment. Obtained the average pretest and posttest amounted to 29.4 and 80.4, respectively. Based on the results of Man-Whitney tests, it can be concluded that the mean pretest and posttest scores differ significantly. This means that the use of animated videos in learning Business Mathematics can improve student learning outcomes.

\section{ARTICLE INFORMATION}

\begin{tabular}{lll}
\hline Keywords & & Article History \\
${$\cline { 1 - 1 }$} \begin{array}{l}\text { Submitted May 8, 2020 } \\
\text { Blended Learning }\end{array}$ Mathematics Learning $}$ & & $\begin{array}{l}\text { Revised Nov 16, 2020 } \\
\text { Accepted Nov 22, 2020 }\end{array}$ \\
\cline { 1 - 1 } Corresponding Author & &
\end{tabular}

Nicky Dwi Puspaningtyas

Universitas Teknokrat Indonesia

Jalan Z.A. Pagar Alam No. 9-11, Bandar Lampung, Indonesia

Email: nicky@teknokrat.ac.id

\section{How to Cite}

Puspaningtyas, N.D. \& Ulfa, M. (2020). Improving Students learning Outcomes in Blended Learning Through the Use of Animated Video. Kalamatika: Jurnal Pendidikan Matematika, 5(2), 133-142. 


\section{INTRODUCTION}

Difference is something that is sure to happen to every student in a class. One difference that can occur in a class is the difference in student learning styles. Puspaningtyas (2019) states that in learning, educators must be able to pay attention to the characteristics of their students. Therefore, teachers must be able to accommodate any differences found in their students. Students who have a visual learning style will more easily imagine abstract objects than students with auditory and kinesthetic learning styles. Therefore, it is sometimes difficult for auditory and kinesthetic learners to understand material about mathematical material.

Mathematics is a basic course that must be mastered by students because it is a prerequisite for further courses. In mathematics courses there is material about graph functions where students must be able to imagine how the graphs occur before they apply it further in their respective scientific fields. In Business Mathematics lectures, graphs are used to show the geometric repesentation of several function, such as Supply and Demand Function, Market Balance Point, Maximum, and Minimum Profit. Because there are variations in learning styles, there will be students who can easily imagine and draw graphics, there are also those who will have difficulty in doing it. Therefore, we need a learning media to facilitate students in learning mathematics material.

Today's students are millennials whose almost all activities interact with gadgets and the internet. Saputra \& Febriyanto (2019) states that educators must innovate learning by utilizing technological developments. Based on research conducted by Pihlap (Widjayanti, Masfingatin, \& Setyansah, 2018), learners will be more motivated to participate in learning activities when using technology-based learning media. The results of the study are in line with the results of research conducted by Samur (2015) which states that learning by using technology can improve student achievement in geometry. Thus, the learning process is needed by using technology that can facilitate students with a variety of learning styles so that it is easy to understand learning material. One of them is by using a blended learning model.

Blended learning is a learning model that combines face-to-face learning in class with elearning learning or online learning (Lin, Tseng, \& Chiang, 2016). This learning can be a facility in strengthening character values through learning material reinforcement activities, learning methods in accordance with curriculum content based on statutory provisions, as stated in Presidential Regulation Number 87 of 2017. Through blended learning, students can learn by 
independent without limited space and time.

Learning with blended learning models combines traditional learning models with internet-based learning models. Throne (in Sjukur, 2012) describes blended learning as an opportunity to integrate the development of innovation and technology offered by learning in networks with the interaction and participation offered in traditional learning. In learning with blended learning, students are given the opportunity to learn independently and be guided. Lin et al. (2016) state that in blended learning, teachers teach in the first few meetings in class. Furthermore, after students truly understand the learning objectives, students can continue learning and interact online. It can be concluded that the role of face-to-face meetings is very much needed to ensure that students know clearly the learning objectives that they will go through online at subsequent meetings.

Along with the changing times and technological advances, blended learning is increasingly popular and widely applied in several educational institutions. Marsh and Drexler (in Lin et al., 2016) argue that blended learning represents all learning models that are integrated with technology, such as electronic mail, video and internet, as well as traditional learning. Thus, learning activities will be easier and varied.

Based on research conducted by Banyen, Viriyavejakul, \& Ratanaolarn (2016), students feel happy learning by using a blended learning model because this learning is a change from conventional learning that facilitates students to interact with computers. Students are encouraged to explore their understanding through online learning which is then applied in classroom learning. The results show that through blended learning, students can understand the material much better than only through traditional learning. In addition, student independence is also formed because students are given the opportunity to learn without face to face with the teacher, discuss with other students, and analyze learning material.

Educators must have pedagogical competence, one of which is integrating with technology in making learning media. According to Bakar, Maat, \& Rosli (2020), educators have self-efficacy in implementing learning that is integrated with technology. On the other hand, Faradillah \& Hadi (2020) state that many teachers find it difficult to carry out online lectures because of the often not read mathematical symbols. Therefore we need a learning media that can facilitate online mathematics learning.

One of the media that can be used in blended learning is animated video learning. Mayer 
(in Lubrick, Zhou, \& Zhang, 2019) argues that individuals learn better through words and pictures compared to learning through pictures alone. It is clear that the animated video presents both words and pictures or diagrams.

Animation is a display that is composed by combining text, graphics, and sound in movement activities (Munir, in Widjayanti et al., 2018) The animation presented can provide a visualization of the concepts that will be conveyed in the media. When students are able to visualize the material faced, students understand the material well. Animation can provide a clear description of the material so that the use of animation in learning can increase students' interest, motivation, and understanding in learning.

Johari (2014) argue that animated video has advantages and disadvantages. The advantages include being able to represent large objects to smaller sizes and vice versa, making it easier for teachers to deliver learning material that is step by step or process, can collaborate audio and visual elements, attract more attention and motivation of students, and provide opportunities for students to study without guidance. Therefore, the application of video animation is very suitable to be applied as a learning media in blended learning. Where students can study independently by viewing material on video without direct tutoring.

On the other hand, video animation also has several disadvantages, namely the large cost of production, requires a relatively long time from making, editing, until the video is useful, requires skill and creativity to package material and design animation. This is in line with the opinion expressed by Butcher (in Lubrick et al., 2019). He concluded that the diagram shown should not be more complicated than needed to communicate basic concepts.

Animated videos allow instructors to present charts or graphs while explaining the process of making the graph. Researchers agree that video-based learning in conjunction with appropriate pedagogical methods has the potential to improve learning outcomes (Yousef, et al. In Lubrick et al., 2019). In addition, Widiyasanti \& Ayriza (2018) also concluded from their research that learning motivation and character of student responsibility can be improved through learning by using video animation.

Although there have been many studies conducted on the use of animated videos in blended learning, there are still few studies that discuss the application of mathematics in economics. The purpose of this study was to determine how student learning outcomes in blended learning using animated videos in business mathematics courses. While the formulation 
of the problem is whether there is a significant increase in student learning outcomes before and after the implementation of blended learning through the use of animated videos.

\section{METHOD}

This research is a quantitative experimental study carried out at the Universitas Teknokrat Indonesia by developing a model proposed by (Creswell, 2017). The subjects in this study were 35 students of Management Study Program of MNJ 19 A class who took Business Mathematics in 2019-2020 academic year. The material in this research is Derivative Function of Algebra.

Pre-test is given to research subjects to obtain data on students' initial abilities. After that, the subject is given treatment that is learning in the network by using video animation animation mathematics learning. Then the subject is given a Post-test that aims to obtain the student's final ability data.

Pre-test and posttest data were used to determine the subject's learning achievement after the implementation of blended learning using animated videos. Pre-test and posttest values were tested statistically using SPSS software. Statistical tests were performed to determine whether there were significant differences between the two tests.

The first statistical test is the normality test. If the data are not normally distributed, then the $\mathrm{U}$ or Mann Whitney test is performed. On the other hand, if both data are normally distributed, then homogeneity test is continued. Furthermore, if the data is homogeneous, a homogeneous data $t$ test is performed. However, if the data are not homogeneous, then the $t$ data test is not homogeneous. The flow of data testing can be seen in figure 1 .

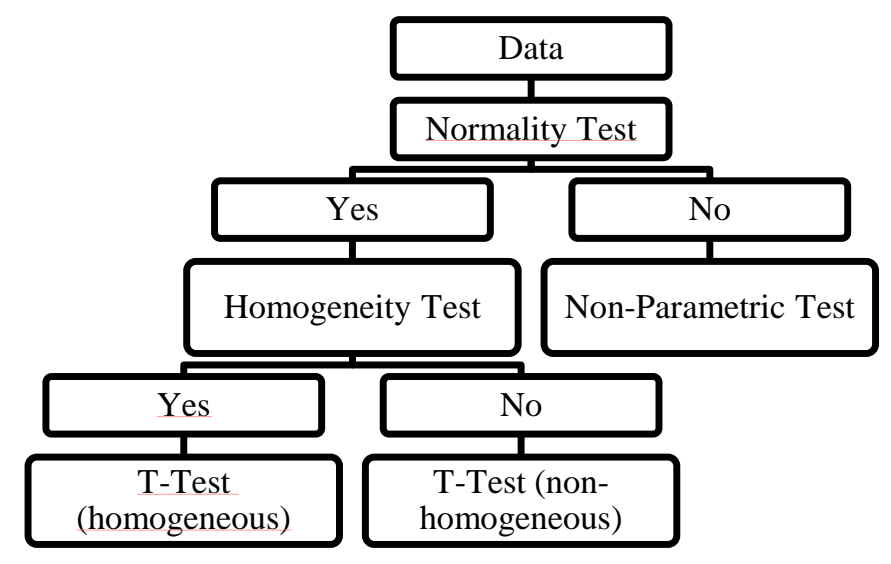

Figure 1. Data Testing Flow Chart. 


\section{RESULT AND DISCUSSION}

Data that has been collected through Pre-Test and Post-Test is tested for normality by using SPSS application. Normality test is a test conducted with the aim to determine whether the distribution of data in a data group or variable is normally distributed or not (Sugiyono, 2010). Table 1 is a data normality test table.

Table 2. Test of Normality Result

\begin{tabular}{cccccccc}
\hline \multirow{2}{*}{ GROUP } & \multicolumn{3}{c}{ Kolmogorov-Smirnov } & \multicolumn{3}{c}{ Shapiro-Wilk } \\
\cline { 3 - 7 } \multicolumn{2}{c}{ SCORE } & Statistic & df & Sig. & Statistic & df & Sig. \\
& POSTTEST & .300 & 35 & .000 & .744 & 35 & .000 \\
& .288 & 35 & .000 & .674 & 35 & .000 \\
\hline
\end{tabular}

From the table 1 , it can be seen that the significance value for pretest $=0,000$ and for posttest $=0,000$. Both of these significance values are less than 0.05 . The data is normally distributed if the significance value is more than 0.05 . Thus, it can be concluded that the pretest and posttest data are not normally distributed. Therefore, the next test is the Non-Parametric Test (Man Whitney-U) as seen in table 2.

Table 2. Non-Parametric Test Result

\begin{tabular}{lr}
\hline & \multicolumn{2}{c}{ SCORE } \\
\hline Mann-Whitney U & 74.500 \\
Wilcoxon W & 704.500 \\
Z & -6.441 \\
Asymp.Sig. (2-tailed) & .000 \\
\hline
\end{tabular}

Based on table 2, a Significance Value of 0,000 was obtained. The test criteria for NonParametric are, the data are stated to have the same average if Sig> 0.05. Thus, it can be concluded that the pretest and posttest data have significant mean differences. When viewed from each average, the pretest data has an average of 29.442 and the average posttest score is 80.442 as seen in table 3 and 4 . It is clear that the posttest average is more than the pretest average and based on statistical test results, the average data is significantly different.

Table 3. Mean of Pre-Test Score

\begin{tabular}{lcc}
\hline & $\mathrm{N}$ & Mean \\
\hline SCORE & 35 & 29.4286 \\
Valid N (listwise) & 35 & \\
\hline
\end{tabular}

Table 4. Mean of Post-Test Score

\begin{tabular}{lcc}
\hline & $\mathrm{N}$ & Mean \\
\hline SCORE & 35 & 80.4286 \\
Valid N (listwise) & 35 & \\
\hline
\end{tabular}

The results of this study indicate that Business Mathematical blended learning through the use of animated videos can improve student learning achievement. This can be seen from 
the results of statistical analysis where there is a significant average difference between student scores before and after learning. The results of this study are in line with the results of the research of Banyen et al., (2016) that through blended learning, students can understand the material much better compared to learning that is only face to face.

The use of learning videos also improves students' mathematical abilities. As stated by Nurwijayanti (2019) that learning media has a role in improving student learning outcomes. Students find it easier to understand blended learning material through the use of animated videos. Even more so if there is a tutor who explains the video as what has been done in this research.

\section{CONCLUSION}

Blended learning is relatively new for students. Furthermore, mathematics material will be more difficult if studied without an explaining tutor. Animated videos can be used as an alternative online learning media. From the results of the study, it was concluded that the use of animated videos can improve student learning achievement. To other researchers, it is advisable to carry out further research with more samples and a longer research period with other mathematical material.

\section{ACKNOWLEDGMENTS}

This scientific article is an output from Penelitian Dosen Pemula (PDP) with grant funding from the Direktorat Riset dan Pengabdian Masyarakat (DRPM) KemenristekBRIN through Universitas Teknokrat Indonesia in 2020 funding. Thus, thanks are extended to DRPM Kemenristekdikti and Universitas Teknokrat Indonesia for the supports so that this research can be carried out well.

\section{REFERENCES}

Bakar, N. S. A., Maat, S. M., \& Rosli, R. (2020). Mathematics Teacher's Self-Efficacy of Technology Integration and Technological Pedagogical Content Knowledge. Journal on Mathematics Education, 11(2), 259-276.

Banyen, W., Viriyavejakul, C., \& Ratanaolarn, T. (2016). A Blended Learning Model for Learning Achievement Enhancement of Thai Undergraduate Students. International Journal of Emerging Technologies in Learning, 11(4). 
Creswell, J. W. (2017). Research Design: Qualitative, Quantitative, and Mixed Methods Approaches. Sage publications.

Faradillah, A., \& Hadi, W. (2020). Educators'perception Of Blended Learning Models On Mathematics Learning. Kalamatika: Jurnal Pendidikan Matematika, 5(1), 83-92.

Johari, A. (2014). Penerapan media video dan animasi pada materi memvakum dan mengisi refrigeran terhadap hasil belajar siswa. Universitas Pendidikan Indonesia.

Lin, Y.-W., Tseng, C.-L., \& Chiang, P.-J. (2016). The Effect of Blended Learning in Mathematics Course. EURASIA Journal of Mathematics, Science and Technology Education, 13(3), 741-770.

Lubrick, M., Zhou, G., \& Zhang, J. (2019). Is the Future Bright? The Potential of Lightboard Videos for Student Achievement and Engagement in Learning. EURASIA Journal of Mathematics, Science and Technology Education, 15(8), em1735.

Nurwijayanti, A. (2019). Combining Google SketchUp and Ispring Suite 8: A Breakthrough to Develop Geometry Learning Media. Journal on Mathematics Education, 10(1), 103-116.

Puspaningtyas, N. D. (2019). Proses Berpikir Lateral Siswa SD dalam Menyelesaikan Masalah Matematika Open-Ended Ditinjau dari Perbedaan Gaya Belajar. MAJAMATH: Jurnal Matematika Dan Pendidikan Matematika, 2(2), 80-86.

Samur, H. (2015). The Effect of Dynamic Geometry Use on Eight Grade Students' Achievement in Geometry and Attitude Towards Geometry on Triangle Topic. Unpublished Master's Thesis). The Graduate School of Social Sciences, Middle East Technical University, Ankara, Turkey.

Saputra, V. H., \& Febriyanto, E. (2019). Media Pembelajaran Berbasis Multimedia Untuk Anak Tuna Grahita. Mathema: Jurnal Pendidikan Matematika, 1(1), 15-23.

Sjukur, S. B. (2012). Pengaruh Blended Learning Terhadap Motivasi Belajar dan Hasil Belajar Siswa di Tingkat SMK. Jurnal Pendidikan Vokasi, 2(3). 
Sugiyono, P. (2010). Metode Penelitian Kuantitatif, Kualitatif, dan R\&D. Bandung: CV Alfabeta.

Widiyasanti, M., \& Ayriza, Y. (2018). Pengembangan Media Video Animasi Untuk Meningkatkan Motivasi Belajar Dan Karakter Tanggung Jawab Siswa Kelas V. Jurnal Pendidikan Karakter, 8(1).

Widjayanti, W. R., Masfingatin, T., \& Setyansah, R. K. (2018). Media Pembelajaran Interaktif Berbasis Animasi Pada Materi Statistika Untuk Siswa Kelas 7 SMP. Jurnal Pendidikan Matematika, 13(1), 101-112. 
142 KALAMATIKA, Volume 5, No. 2, November 2020, pages 133-142 